\title{
An Improved Methodology For Absorption Costing: Efficiency Based Absorption Costing (EBAC)
}

\author{
Samuel Jebaraj Benjamin, Multimedia University, Cyberjaya Campus, Malaysia \\ Saravanan Muthaiyah, Multimedia University, Cyberjaya Campus, Malaysia \\ M. Srikamaladevi Marathamuthu, Multimedia University, Cyberjaya Campus, Malaysia
}

\begin{abstract}
This paper presents an improved, efficiency based absorption costing method. Efficiency based absorption costing EBAC represent an algorithm that absorbs costs based on efficiency as the main driver and we compare its results with other methods such as $A B C$ as proof-of-concept. $E B A C$ results in significant cost changes compared to $A B C$ and the traditional costing system (TCS). Businesses could embrace the more efficient EBAC for a host of their pertinent cost control and decision making needs. The EBAC methodology is both easy and convenient to apply as firms currently using $A B C$ could instantly explore EBAC without the need to gather extra information.
\end{abstract}

Keywords: Absorption costing, Efficiency Based Absorption Costing, Activity Based Costing, Traditional Costing System

\section{INTRODUCTION}

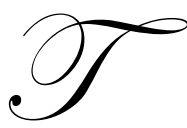

he efficiency of traditional cost and management accounting practices, especially in the area of absorption costing in coping with the requirements of the modern business environment and technology have been of major concern for a number of years. The perceived gap in timeliness and accuracy of the Traditional Costing System (TCS) (Cooper and Kaplan 1991; Gunasekaran et al. 1999) has become a major impetus for management accounting innovation (Chenhall 2003; Smith 2000; Lukka and Shields 1999). The nature of the current manufacturing environment for example, which are more capital intensive compared to the traditional labor intensive environment render the TCS less applicable. The solution to the much needed change in the TCS came in the form of Activity Based Costing (ABC), (Johnson and Kaplan 1987). Eventually the many articles published on the design and implementation of ABC includes (Coskins 1997; Lyne and Friedman 1996; Scheeweiss 1998; Sohal and Chung 1998; Zhuang and Burns 1992).

Shields (1995) reported the growing interest over the two decades of firms seeking to implement the ABC systems as the more accurate way of allocating operating costs to various cost objects. ABC was seen as sophisticated enough to measure the multiple level resources required to produce different products (Nazmi et al. 2007; Ruhl and Hartman 1998). Subsequently ABC has been applied to a variety of companies and economic sectors, for example education (Acton and Cotton 1997; Nazmi et al. 2007), health care (Aird 1996; Michela and Irvine 2005, financial services (Adams 1996), logistic (Baykasoglu and Kaplanoglu 2007) food and beverage (Magdy and Luther 2006), manufacturing (Ruhanita and Daing, 2007; John Innes and Sinclair 2000; Steve R. and Ken 1994; John A. et al. 2001; Dhavale 1993; Zhuang and Burns 1992; (Baykasoglu et al. 2006) and retail (Tony and Philip 2001). Although ABC was hailed as being able to allocate overheads to products more accurately, provide better pricing decisions and better resource allocations (John A. et al. 2001) one of the key weaknesses of $\mathrm{ABC}$ and TCS is the use of the "blanket overhead absorption rate" to allocate costs. To understand this phenomenon, it is important to explore the evolution of the TCS and ABC in more detail. 


\section{THE ABSORPTION COSTING PROBLEM}

Disagreement still exist, albeit not as heated as decades ago, on the merits of variable or marginal costing versus full costing or absorption costing. In full costing, fixed production costs or overheads are allocated to products so that the reported product cost measure total manufacturing costs. In variable costing, the fixed costs are not allocated and product costs reflect only the marginal cost of manufacturing (Cooper and Kaplan 1988). Debate on the merits of cost allocation and its impact used to be prominent decades ago as pointed by earlier studies, for example, (Zimmerman 1979). However despite the arbitrary nature of cost allocations (Thomas 1969), behavioral pricing studies have suggested that different decision outcomes are related to the method of cost allocation (Bloom et al. 1984; Barnes and Webb 1986). It was found that unitization and allocation of fixed cost to products can result in decisions that lead to less than optimum output level, if decisions makers treat these cost measures as if they were variable. However while accounting literature and academics concentrated on the merits of variable costing or full costing, businesses continued to use absorption costing as the fundamental input in pricing, (Cooper and Kaplan, 1988; Govindarijian \& Anthony 1983; Gordon et al. 1981). Among the reasons for the wide spread adoption of full costing as opposed to marginal costing is because managers rejected the idea that product decisions have short term time horizon impact but in fact, decisions to offer a product creates long term commitment to manufacturer, market and support that product and hence the short term based marginal costing is inadequate to measure product cost (Cooper and Kaplan 1988). Analytical works have also revealed that absorption costing more closely represents the underlying cost functions facing firms, (Lere 1986a; Dickhaut and John C. 1983; Lere 1982). In this regard, the traditional costing (TCS) coined in this study denote the full costing or absorption costing.

Traditional costing systems (TCS) have its roots in the manufacturing industry. The TCS is characterized by absorption of production overheads (excluding selling and administration overheads) into product costs, the use of direct labor hours or labor costs as a "convenient" or "easy" way to allocate total overhead to products and the use of the blanket overhead recovery costs for simplicity purposes (Steve R. and Ken 1994; Gunasekaran et al. 1999). The exclusion of selling and administration overheads from being absorbed into products costs originate from the annals of financial accounting and reporting requirements for stock valuation purposes. While the inclusion of the selling and administrative costs is desirable for product related decisions, their exclusion from being absorbed caused Johnson and Kaplan (1987) to lament that management accounting has become of secondary importance in comparison to financial accounting. Similarly Bailey (1991), Drury et al. (1993), and Drury and Tayles (2000) found that product cost information tend to prepared on a similar basis to financial accounting. As the labor intensive manufacturing industry gradually shifted towards more capital intensive, companies started using machine hours instead of labor hours to allocate costs from cost pools to products (Cooper and Kaplan 1998). However the increased use of automation and computerized services would mean relying primarily on direct labor or machine hours can produce large distortions in the allocation of overheads costs (Snyder and Davenport 1997). Additionally the support departments costs of companies have been among the fastest growing in relation to overall cost structure of manufactured goods (Baykasoglu et al. 2003). In other words, increasingly labor costs accounted for a smaller proportion of a company's overall costs. In this regard, the use of the blanket overhead recovery to allocate total overheads does not take into account the actual usage of overheads, either by department or by product.

Thus the need for more accurate costing of products and services has led to the widespread adoption of $\mathrm{ABC}$. $\mathrm{ABC}$ has been developed to provide more accurate ways of assigning the costs of indirect and support resources to activities, business processes, products, services and customers (Kaplan R. 1998). In ABC an attempt was made to track overheads to cost units (which are the units that generated the overhead cost) as accurately as possible. In reality, this represents a return to the kind of costing methods used before the need for financial reports (Steve R. and Ken 1994).

Figure 1 represents the cost assignment process in ABC, (Tsai and Kuo, 2004). The first stage of cost accumulation in $\mathrm{ABC}$ is the activity centers. In the first stage resources are allocated to the activity centers or in other words the actions are aggregated into activities. Once the resources are allocated to the activity centers, the cost of the activity centre is reported. The second stage of $A B C$ is the allocation of activity costs to cost objects. First selection of appropriate cost drivers have to be made. Following this cost will be allocated to the cost objects. It should be noted that $\mathrm{ABC}$ has rightfully pointed out the vagueness of analyzing and allocating total overheads to products and therefore the need to analyze or segregate total overheads into more detailed-defined overheads for 
absorption purposes. Secondly, $\mathrm{ABC}$ exposed the weakness of using a single blanket overhead recovery rate and therefore the need to absorb each type of overheads based on their respective cost drivers. In essence ABC is an extension of the TCS. It extended the bases for splitting the overheads into multiple bases from the previous single base. Next ABC demonstrated the need for the inclusion of support department overheads into product costs. Whilst the above three major improvements are salient and reflected the leap in management accounting practices, one key weakness of the TCS remains partly unresolved in ABC, which is the use a single standard absorption rate for each cost pool, determined by its cost driver .

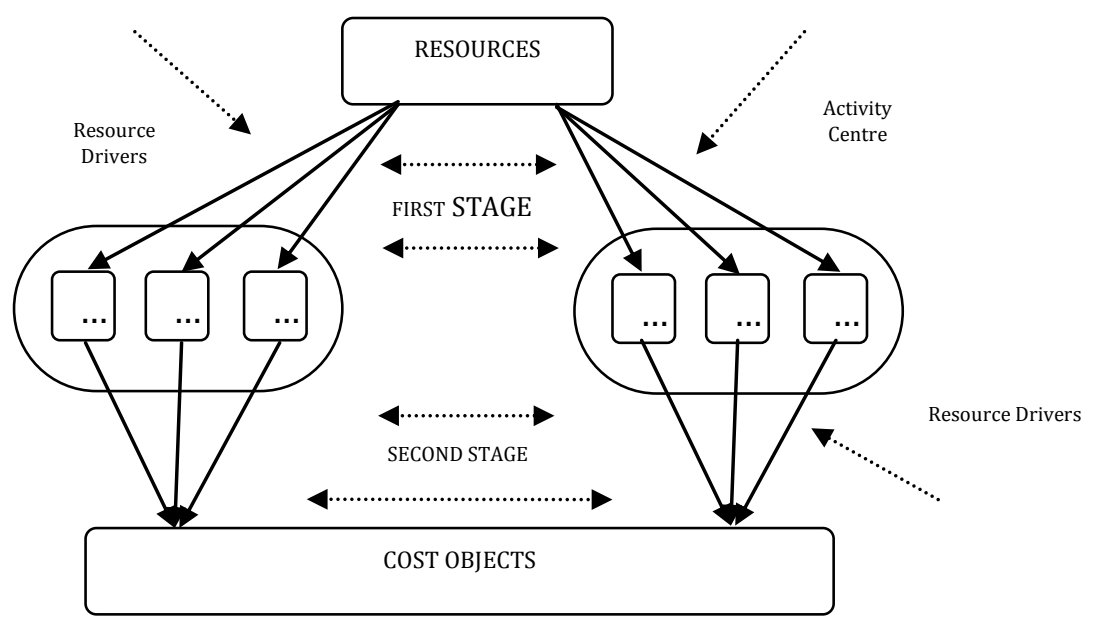

Figure 1 - Cost Assignment of ABC

Source: Tsai \& Kuo, 2004.

The use of the single standard absorption rate for each cost pool, determined by its cost driver. Currently $\mathrm{ABC}$ derives the absorption rate for each of its cost pool by dividing the total costs of each pool with total number of units of cost drivers for that particular cost pool, thus using the overhead absorption rate per cost driver. The absorption rate per cost driver is then used to calculate and absorb the cost absorbed for each cost objects or products. In order to demonstrate the point discussed, an illustration in Scenario 1 is given below:

\section{Scenario 1}

Ruth Book Publishing Plc publishes two types of books. One is a children's book (CHB) and one is a magazine (MGZ). One of the overhead costs incurred by Ruth is quality control cost which amounts to $\$ 800,000$. The cost driver of the quality control cost is number of inspections.

The details of Ruth's annual output are as follow:

$\begin{array}{lcc}\text { Book } & \text { Output (copies) } & \text { Cost driver }- \text { No of inspections } \\ \text { CHB } & 1,000,000 & 180 \text { times } \\ \text { MGZ } & 120,000 & 20 \text { times }\end{array}$

Using the $\mathrm{ABC}$ the overhead absorption rate calculated would as follow:

$$
\text { Quality control cost } / \text { driver }=\frac{\$ 800,000}{200}=\$ 4,000 / \text { driver }
$$

The total quality control cost overhead absorbed by CHB would therefore be $\$ 720,000$ 16(i.e.180 X $\$ 4,000$ ) and MGZ \$80,000 (i.e. 20 X \$4,000).

It should be noted in the scenario above $\mathrm{ABC}$ uses a single standard absorption rate of $\$ 4,000$ per driver to absorb the quality control costs incurred by CHB and MGZ. The apparent weakness of this approach is that it ignores the different level of efficiency of each product (CHB or MGZ) in using or incurring the quality control 
costs. It is clear that the efficiency of CHB and MGZ in incurring the quality control cost is different as CHB needed 180 inspections for 1,000,000 of its output while MGZ needed 20 inspections for 120,000 of its output. Therefore assigning a standard absorption rate of $\$ 4,000$ for both products is therefore fundamentally incorrect and unfair to both products as each have possess different efficiency characteristics in incurring the quality control costs. In today's' modern and competitive business environment companies have adopted efficient concepts such as Just-inTime (JIT), Total Quality Management (TQM) and lean manufacturing where efficiency rules as the central theme of operations. Assigning a single standard absorption rate for all products that jointly incur a particular overhead cost would result in high degree of cross subsidization between more efficient and less efficient products. As a result of this, an improved, efficiency based absorption costing methodology is required to rightfully absorb overheads.

\section{METHODOLOGY}

We propose an efficiency based absorption costing (EBAC) and it takes into account the different level of overhead utilization efficiency of different products. The management accounting literature gives four possible methods for determining the denominator activity level used to calculate overhead rates. These four methods are the theoretical maximum capacity, practical capacity, normal capacity and budgeted capacity (John A. et al. 2001). ABC has rightfully argued that it is resource consumption based model and should therefore use the practical capacity as the denominator level (Cooper and Kaplan 1992). The proposed EBAC also adopts the practical capacity to determine the overhead absorption rate, based on the same ground as $\mathrm{ABC}$, which rejected the use of budgeted capacity on the grounds that is could lead distorted product costs and incorrect decisions.

The EBAC uses efficiency as the main determinant to calculate the absorption rate. Efficiency is defined here as the ratio of input required to produce an output. An output or product or service is efficient if it requires lesser input to produce a given number of outputs. For example if Product A needs 10 set up to produce 100 of its units and Product B needs 20 set up to produce 100 of its units, Product A is more efficient. This is because Product A needs lesser input or drivers to produce a given number of outputs. In the literature, the efficiency defined here is also called yield. However, this paper adopts the term efficiency to explain the ratio of input required to produce an output.

In this regard, using the same information from Scenario 1 above, the following methodology for efficiency based absorption costing (EBAC) is proposed;

\begin{tabular}{|c|c|c|c|c|}
\hline \multicolumn{5}{|c|}{ Scenario 1 (a) } \\
\hline Efficiency rate of $\mathrm{CHB}$ & $=$ & $180 / 1,000,000$ & $=$ & 0.0002 \\
\hline Efficiency of rate MGZ & $=$ & $20 / 120,000$ & $=$ & $\underline{0.00016}$ \\
\hline Total efficiency & & & & 0.00036 \\
\hline
\end{tabular}

\begin{tabular}{cc}
\multicolumn{2}{c}{ EBAC } \\
CHB & $0.0002 / 0.00036$ \\
MGZ & $0.00016 / 0.00036$
\end{tabular}

The efficiency rate is obtained by dividing the number cost drivers for a particular product with the total number of units or volume of that product. The total quality control cost overhead absorbed by CHB would therefore be $\$ 415,385$ [i.e. $(0.0002 / 0.00036) X \$ 800,000$ ] and MGZ 384,615 [i.e. $(0.00016 / 0.00036) X \$ 800,000$ ]

MGZ has been slightly more efficient than CHB in incurring or using the quality control overhead cost. This is indicated by the efficiency rate of 0.0002 and 0.00016 for CHB and MGZ respectively. A product with a lower value of efficiency rate indicates better efficiency and thus enjoys a lower absorption rate compared to its less efficient counterparts. The results of the overhead absorption using the EBAC are in stark contrast with results obtained using ABC. The quality control cost overhead absorbed by using EBAC for CHB is lower by $42 \%$ and higher by $381 \%$ for MGZ in absolute amounts as compared to ABC. These results show significant distortion of cost information of CHB and MGZ. As argued earlier, assigning a single standard absorption rate for all products that jointly incur a particular overhead cost would result in high degree of cross subsidization between more efficient and 
less efficient products. The results of Scenario 1 clearly show by using ABC, CHB has been penalized with a high share of the overhead cost while both CHB and MGZ has been nearly similar in their efficiency level in utilizing overhead cost.

Since EBAC is applicable like ABC to all industries, three comprehensive cases comprising one each from the manufacturing, retail and service industry is given below, clearly showing the accuracy of EBAC versus ABC and TCS.

\section{Manufacturing Industry Scenario}

Kino Publishing Co publishes two forms of book. The company publishes a children's book (CHB) and second a magazine (MGZ). The direct costs and other information per unit for each of the two books are as follows:

$\begin{array}{lll} & \text { CHB } & \text { MGZ } \\ \text { Paper costs } & \$ 0.8 & \$ 0.1 \\ \text { Printing costs } & \$ 1.5 & \$ 4.5 \\ \text { Machine costs } & \$ 1.2 & \$ 2.0 \\ \text { Machine hours } & 6 \text { minutes } & 10 \text { minutes } \\ \text { Selling price } & \$ 9.30 & \$ 14.00 \\ \text { Total output units } & 1,000,000 \text { units } & 120,000 \text { units } \\ \text { No of inspection } & 180 & 200 \\ \text { No of set up } & 4 & 12 \\ \text { Total machine hours } & 100,000 & 20,000\end{array}$

CHB needs six minutes of machine time to produce each book, whereas the MGZ needs 10 minutes per book. The machines cost $\$ 12$ per hour to run. The three overheads of Kino Publishing are:

$\begin{array}{lll} & \$ & \text { Cost driver } \\ \text { Property costs hours } & 2,160,000 & \text { Machine } \\ \text { Quality control } & 668,000 & \text { Inspection } \\ \text { Production set up costs } & 52,000 & \text { Set up } \\ \text { Total } & 2,880,000 & \end{array}$

Total output of CHB would be 1,000,000 and MGZ 120,000. Therefore total machine hours consumed by CHB would be 100,000 hours or 6,000,000 minutes and MGZ would be 20,000 hours or 1,200,000 minutes. The absorption of total overhead under the traditional costing system (TCS) is based on the machine hours. The ABC and EBAC use the cost driver information to calculate the absorption rate for each type of overhead.

Table 1 Calculation of TCS overhead absorption rate - Kino Publishing Co

\begin{tabular}{|l|c|c|c|}
\hline Cost Pool & RM & Driver & AR \\
\hline Total overhead costs & $2,880,000$ & Machine hours & $2,880,000 / 120,000=24$ per hour \\
\hline
\end{tabular}

Note: a) $\mathrm{AR}=$ absorption rate

Table 2 Calculation of ABC overhead absorption rate- Kino Publishing Co

\begin{tabular}{|c|c|c|c|c|c|c|c|c|}
\hline Cost Pool & RM & \multicolumn{2}{|c|}{ Driver } & $\begin{array}{c}\text { AR/ } \\
\text { Driver }\end{array}$ & CHB & $\begin{array}{c}\text { Overhead/ } \\
\text { unit }\end{array}$ & MGZ & $\begin{array}{c}\text { Overhead/ } \\
\text { unit }\end{array}$ \\
\hline $\begin{array}{c}\text { Property } \\
\text { costs }\end{array}$ & $2,160,000$ & $\begin{array}{c}\text { Machine } \\
\text { hours }\end{array}$ & 120,000 & 18.00 & $18 \times(6 / 60)$ & 1.8 & $18 \times 10 / 60$ & 3.00 \\
\hline $\begin{array}{c}\text { Quality } \\
\text { control }\end{array}$ & 668,000 & $\begin{array}{c}\text { Number of } \\
\text { inspections }\end{array}$ & 200 & 3340.00 & $\begin{array}{c}(180 \times 3340) \\
/ 1,000,000\end{array}$ & 0.6012 & $\begin{array}{c}(20 \times 3340) \\
/ 120,000\end{array}$ & 0.56 \\
\hline $\begin{array}{c}\text { Production } \\
\text { set up }\end{array}$ & 52,000 & $\begin{array}{c}\text { Number of set } \\
\text { ups }\end{array}$ & 16 & 3250.00 & $\begin{array}{c}(4 \times 3250) / \\
1,000,000\end{array}$ & 0.013 & $\begin{array}{c}(12 \times 3250) \\
/ 120,000\end{array}$ & 0.325 \\
\hline & $2,880,000$ & & & & & & & \\
\hline
\end{tabular}

Note: a) $\mathrm{AR}=$ absorption rate 
Table 3 Calculation of EBAC overhead absorption rate- Kino Publishing Co

\begin{tabular}{|c|c|c|c|c|c|c|c|c|c|}
\hline Cost Pool & $\mathrm{RM}$ & Driver & $\mathrm{CHB}$ & $\begin{array}{c}\text { No of } \\
\text { units }\end{array}$ & ER & MGZ & $\begin{array}{c}\text { No of } \\
\text { units }\end{array}$ & ER & Total ER \\
\hline $\begin{array}{l}\text { Property } \\
\text { costs }\end{array}$ & $2,160,000$ & $\begin{array}{l}\text { Machine } \\
\text { hours or } \\
\min \end{array}$ & $6,000,000$ & $1,000,000$ & 6.00 & $1,200,000$ & 120,000 & 10.00 & 16.00 \\
\hline $\begin{array}{l}\text { Quality } \\
\text { control }\end{array}$ & 668,000 & $\begin{array}{l}\text { Number of } \\
\text { inspections }\end{array}$ & 180 & $1,000,000$ & 0.0002 & 20 & 120,000 & 0.000166667 & 0.0003 \\
\hline \multirow[t]{2}{*}{$\begin{array}{l}\text { Production } \\
\text { set up }\end{array}$} & 52,000 & $\begin{array}{l}\text { Number of } \\
\text { set ups }\end{array}$ & 4 & $1,000,000$ & 0.000004 & 12 & 120,000 & 0.0001 & 0.000104 \\
\hline & $2,880,000$ & & & & & & & & \\
\hline $\begin{array}{ll}\text { Note: } & \text { a) } \\
& \text { b) } \\
& \text { (i) } \\
& \text { c) } \\
& \text { (i) } \\
& \text { d) } \\
& \text { (i) }\end{array}$ & $\begin{array}{l}\mathrm{R}=\text { Efficien } \\
\text { roperty cost } \\
\mathrm{CHB}=6,000, \\
\text { Quality contro } \\
\mathrm{CHB}=180 / \\
\text { roduction set } \\
\mathrm{CHB}=4 / 1,0\end{array}$ & $\begin{array}{l}\text { rate } \\
R \text { for } \\
00 / 1,000,000 \\
\text { cost ER for } \\
000,000=0.00 \\
\text { p cost ER for } \\
, 000=0.0000\end{array}$ & $\begin{array}{l}=6.00, \\
2, \\
4,\end{array}$ & $\begin{array}{l}\text { (ii) } \mathrm{M} \\
\text { (ii) } \mathrm{M} \\
\text { (ii) } 12\end{array}$ & $\mathrm{Z}=20 / 120$ & $00=0.0001$ & 0.00 & & \\
\hline
\end{tabular}

Table 4 Cost and Profitability of CHB and MGZ under different costing methods - Kino Publishing Co

\begin{tabular}{|c|c|c|c|c|c|c|c|c|c|c|}
\hline & \multirow{2}{*}{\multicolumn{3}{|c|}{$\mathrm{CHB}$}} & \multirow{2}{*}{\multicolumn{3}{|c|}{ MGZ }} & \multicolumn{4}{|c|}{ Percentage of Change vs. EBAC } \\
\hline & & & & & & & \multicolumn{2}{|c|}{$\mathrm{CHB}$} & \multicolumn{2}{|c|}{ MGZ } \\
\hline & TCS & $\mathrm{ABC}$ & EBAC & TCS & $\mathrm{ABC}$ & EBAC & TCS & $\mathrm{ABC}$ & TCS & $\mathrm{ABC}$ \\
\hline Sales price & 9.3 & 9.3 & 9.3 & 14.0 & 14.0 & 14.0 & & & & \\
\hline Paper costs & 0.8 & 0.8 & 0.8 & 0.1 & 0.1 & 0.1 & & & & \\
\hline Printing costs & 1.5 & 1.5 & 1.5 & 4.5 & 4.5 & 4.5 & & & & \\
\hline Machine cost & 1.2 & 1.2 & 1.2 & 2.00 & 2.00 & 2.00 & & & & \\
\hline Contribution & 5.8 & 5.8 & 5.8 & 7.4 & 7.4 & 7.4 & & & & \\
\hline Overheads & 2.4 & & & 4.00 & & & & & & \\
\hline Property costs & & 1.8 & 0.81 & & 3.00 & 11.25 & & & & \\
\hline Quality control (QC) & & 0.6012 & 0.35 & & 0.56 & 2.68 & & & & \\
\hline Production set up & & 0.013 & 0.002 & & 0.33 & 0.42 & & & & \\
\hline Profit & 3.4 & 3.39 & 4.64 & 3.40 & 3.52 & -6.94 & $36.5 \%$ & $37 \%$ & $-304 \%$ & $-298 \%$ \\
\hline
\end{tabular}

Note: a) TCS Overheads absorption rate for

(i) $\mathrm{CHB}=6$ mins at $\mathrm{RM} 24 / \mathrm{hr}=2.4$,

b) $\mathrm{ABC}$ Overhead absorption rate of Property Costs for

(i) $\mathrm{CHB}=18 \mathrm{X}(6 / 60)=1.8$,

c) ABC Overhead absorption rate of QC Cost for

(i) $\mathrm{CHB}=(180 \mathrm{X} 3340) / 1,000,000=0.6012$,

d) $\mathrm{ABC}$ Overhead absorption rate of Production set up Cost for

(i) $\mathrm{CHB}=(4 \mathrm{X} 3250) / 1,000,000=0.013$,

e) EBAC Overhead absorption rate of Property Costs for

(i) $\mathrm{CHB}=[(6 / 16) \mathrm{X} 2,160,000] / 1,000,000=0.81$,

f) EBAC Overhead absorption rate of Quality Control Cost for

(i) $\mathrm{CHB}=[(0.0002 / 0.0003) \times 668,000] / 1,000,000=0.35$,

g) EBAC Overhead absorption rate of Production set up Cost for

(i) $\mathrm{CHB}=[(0.00004 / 0.000104) \times 52,000] / 1,000,000=0.002$, (ii) $\mathrm{MGZ}(10$ mins at $\mathrm{RM} 24 / \mathrm{hr}=4.00$

(ii) $\mathrm{MGZ}=18 \mathrm{X}(10 / 60)=3.00$

(ii) $\mathrm{MGZ}=(20 \mathrm{X} 3340) / 120,000=0.56$

(ii) $\mathrm{MGZ}=(12 \mathrm{X} 2350) / 120,000=0.33$

(ii) $\mathrm{MGZ}=[(10 / 16) \mathrm{X} 2,160,000] / 120,000=11.25$

(ii) $\mathrm{MGZ}=[(0.000167 / 0.0003) \mathrm{X} 668,000] / 120,000=2.68$

(ii) $\mathrm{MGZ}=[(0.0001 / 0.000104) \mathrm{X} 52,000] / 120,000=0.42$

The information given in Table 4 is costing information calculated for each unit of CHB and MGZ. It can be seen from the analysis above that the profitability of the CHB and MGZ using the TCS or ABC is almost the same. However using EBAC, it clear that CHB is the profitable one, and MGZ has actually been making a loss. The more efficient CHB have been subsidizing MGZ when the overhead cost is absorbed using the TCS or ABC. The percentage of change in profitability from adopting the more accurate EBAC as compared to TCS or ABC is very significant at $36.5 \%$ and $37 \%$ for CHB and $-304 \%$ and $-298 \%$ for MGZ. 


\section{Trading/ Retail Industry Scenario}

Home Style owns several home furnishing stores. Consultants give personalized attention to potential customers and also visit their homes in necessary. Customers visit the store to make their selections after which sales staff collect payment and raise purchase order. Customers then collect their Do-It-Yourself (DIY) goods from the warehouse, using the purchase order as authority to collect. Administration staffs process orders and also arranges consultations. Each store operates an absorption costing system and costs other than the cost of goods sold are apportioned on the basis of sales floor are under the Traditional Costing System (TCS).

Results of Home Style for the first six months are as follows:

\begin{tabular}{|c|c|c|c|c|}
\hline & Kitchens & Bathrooms & Dining Rooms & Total \\
\hline Department & $\$$ & $\$$ & $\$$ & $\$$ \\
\hline Sales & 210,000 & 112,500 & 440,000 & 762,500 \\
\hline Cost of goods sold & 63,000 & 37,500 & 176,000 & 276,500 \\
\hline Other costs & $\underline{130,250}$ & $\underline{81,406}$ & 113,968 & $\underline{325,624}$ \\
\hline Profit & $\underline{16,750}$ & $\underline{113,968}$ & $\underline{150,032}$ & $\underline{160,376}$ \\
\hline
\end{tabular}

The 'Other costs' above consist of fixed overheads for Home Furnishing is made up of the following:

$\$$

Sales staff wages

Consultation staff wages

Warehouse staff wages

Administration staff wages

General overheads (light, heat, rates, etc)

\begin{tabular}{cc}
64,800 & 12 \\
24,960 & 4 \\
30,240 & 6 \\
30,624 & 4 \\
175,000 & \\
\hline 325,624 &
\end{tabular}

The following information of Home Furnishing is available to calculate the overhead absorption rate using ABC and EBAC.

$\begin{array}{lccc}\text { Department } & \text { Kitchens } & \text { Bathrooms } & \text { Dining Rooms } \\ \text { Number of items sold } & 1,000 & 1,500 & 4,000 \\ \text { Purchase orders } & 1,000 & 900 & 2,500 \\ \text { Floor area (square meters) } & 16,000 & 10,000 & 14,000 \\ \text { Number of consultations } & 798 & 200 & 250\end{array}$

The calculation of the overhead absorption rate using the TCS, ABC and EBAC is given below:

Table 5 Calculation of TCS overhead absorption rate - Home Style

\begin{tabular}{|l|c|c|c|}
\hline Cost Pool & $\$$ & Driver & OAR \\
\hline Total overhead costs & 325,624 & floor area & $325,624 / 40,000=8.141$ \\
\hline
\end{tabular}

Table 6 Calculation of ABC overhead absorption rate- Home Style

\begin{tabular}{|l|c|l|c|c|}
\hline Cost Pool & RM & \multicolumn{1}{|c|}{ Driver } & AR/Driver \\
\hline Sales staff wages & 64,800 & no of purchase orders & 4,400 & 14.727 \\
Consultation staff wages & 24,960 & no of consultations & 1,248 & 20.00 \\
Warehouse staff wages & 30,240 & no of items sold & 6,500 & 4.652 \\
Administration staff wages & 30,624 & no of tasks & 5,648 & 5.422 \\
General overheads (light, heat, rates, etc.) & 175,000 & floor area & 40,000 & 4.375 \\
\hline
\end{tabular}

Note: a) $\mathrm{AR}=$ Absorption rate 
Table 7 Calculation of EBAC overhead absorption rate - Home Style

\begin{tabular}{|c|c|c|c|c|c|c|c|c|c|c|c|c|c|}
\hline \multirow[b]{2}{*}{ Cost Pool } & \multirow[b]{2}{*}{$\$$} & \multirow[b]{2}{*}{ Driver } & \multicolumn{2}{|c|}{ Kitchens } & \multirow[b]{2}{*}{ ER } & \multicolumn{2}{|c|}{ Bathrooms } & \multirow[b]{2}{*}{ ER } & \multicolumn{2}{|c|}{ Dining Rooms } & \multirow[b]{2}{*}{ ER } & \multirow{2}{*}{$\begin{array}{c}\text { Total } \\
\text { number } \\
\text { of drivers }\end{array}$} & \multirow[b]{2}{*}{$\begin{array}{c}\text { Total } \\
\text { ER }\end{array}$} \\
\hline & & & $\begin{array}{l}\text { No of } \\
\text { drivers }\end{array}$ & $\begin{array}{l}\text { No of } \\
\text { units }\end{array}$ & & $\begin{array}{l}\text { No of } \\
\text { drivers }\end{array}$ & $\begin{array}{l}\text { No of } \\
\text { units }\end{array}$ & & $\begin{array}{l}\text { No of } \\
\text { drivers }\end{array}$ & $\begin{array}{l}\text { No of } \\
\text { units }\end{array}$ & & & \\
\hline Sales staff wages & 64,800 & $\begin{array}{c}\text { No of purchase } \\
\text { orders }\end{array}$ & 1,000 & 1000 & 1.00 & 900 & 1500 & 0.600 & 2,500 & 4000 & 0.625 & 4,400 & 2.225 \\
\hline Consultation staff wages & 24,960 & $\begin{array}{c}\text { No of } \\
\text { consultations }\end{array}$ & 798 & 1000 & 0.80 & 200 & 1500 & 0.133 & 250 & 4000 & 0.063 & 1,248 & 0.994 \\
\hline Warehouse staff Wages & 30,240 & No of items sold & 1,000 & 1000 & 1.00 & 1,500 & 1500 & 1.000 & 4,000 & 4000 & 1.000 & 6,500 & 3.000 \\
\hline Administration staff wages & 30,624 & No of tasks & 1,798 & 1000 & 1.80 & 1,100 & 1500 & 0.733 & 2,750 & 4000 & 0.688 & 5,648 & 3.219 \\
\hline General overheads & 175,000 & Floor area & 16,000 & 1000 & 16.00 & 10,000 & 1500 & 6.667 & 14,000 & 4000 & 3.500 & 40,000 & 26.167 \\
\hline
\end{tabular}

Note: a) ER = Efficiency rate

b) Sales staff wages cost ER for

(i) Kitchen $=1,000 / 1,000=1.00$, (ii) Bathroom $=900 / 1,500=0.6$, (iii) Dining Room $=2,500 / 4000=0.625$

c) Consultation staff wages cost ER for

(i) Kitchen $=798 / 1,000=0.8$, (ii) Bathroom=200/1,500=0.133, (iii) Dining Room=250/4,000=1.00

d) Warehouse staff wages cost ER for

(i) Kitchen=1,000/1,000=1.00, (ii) Bathroom $=1,500 / 1,500=1.00$,(iii) Dining Room $=4,000 / 4,000=1.00$

e) Administration staff wages cost ER for

(i) Kitchen $=1,798 / 1,000=1.80$, (ii) Bathroom $=1,100 / 1,500=0.733$, (iii) Dining Room=2,750/4,000=0.688

f) General overhead cost ER for

(i) Kitchen $=16,000 / 1,000=16.0$, (ii) Bathroom $=10,000 / 1,500=6.667$,

(iii) Dining Room $=14,000 / 4,000=3.50$ 
Table 8 Cost and Profitability of Products under different costing methods - Home Style

\begin{tabular}{|c|c|c|c|c|c|c|c|c|c|c|c|c|}
\hline \multirow{3}{*}{ Product } & \multicolumn{3}{|c|}{ Kitchens } & \multicolumn{3}{|c|}{ Bathrooms } & \multicolumn{3}{|c|}{ Dining Rooms (DR) } & \multicolumn{3}{|c|}{ Total } \\
\hline & $\$$ & $\$$ & $\$$ & $\$$ & $\$$ & $\$$ & $\$$ & $\$$ & $\$$ & $\$$ & $\$$ & $\$$ \\
\hline & TCS & $\mathrm{ABC}$ & EBAC & TCS & $\mathrm{ABC}$ & EBAC & TCS & $\mathrm{ABC}$ & EBAC & TCS & $\mathrm{ABC}$ & EBAC \\
\hline Sales & 210,000 & 210,000 & 210,000 & 112,500 & 112,500 & 112,500 & 440,000 & 440,000 & 440,000 & 762,500 & 762,500 & 762,500 \\
\hline Cost of goods sold & 63,000 & 63,000 & 63,000 & 37,500 & 37,500 & 37,500 & 176,000 & 176,000 & 176,000 & 276,500 & 276,500 & 276,500 \\
\hline Contribution & 147,000 & 147,000 & 147,000 & 75,000 & 75,000 & 75,000 & 264,000 & 264,000 & 264,000 & 486,000 & 486,000 & 486,000 \\
\hline Other costs: total & 130,250 & & & 81,406 & & & 113,968 & & & 325,624 & & \\
\hline Sales staff wages & & 14727 & 29124 & & 13255 & 17474 & & 36818 & 18202 & & 64800 & 64800 \\
\hline $\begin{array}{l}\text { Consultation staff } \\
\text { wages }\end{array}$ & & 15960 & 20042 & & 4000 & 3349 & & 5000 & 1570 & & 24960 & 24960 \\
\hline $\begin{array}{l}\text { Warehouse staff } \\
\text { wages }\end{array}$ & & 4652 & 10080 & & 6978 & 10080 & & 18609 & 10080 & & 30240 & 30240 \\
\hline $\begin{array}{l}\text { Administration } \\
\text { staff wages }\end{array}$ & & 9749 & 17106 & & 5964 & 6977 & & 14911 & 6541 & & 30624 & 30624 \\
\hline $\begin{array}{l}\text { General overheads } \\
\text { (Light, heat, rates, } \\
\text { etc.) }\end{array}$ & & 70000 & 107006 & & 43750 & 44586 & & 61250 & 23408 & & 175000 & 175000 \\
\hline Profit & 16,750 & 31,911 & $-36,358$ & $-6,406$ & 1,053 & $-7,466$ & 150,032 & 127,412 & 204,200 & 160,376 & 160,376 & 160,376 \\
\hline
\end{tabular}

Note:

(i) Kitchen $=(325,624 / 40,000) \times 16,000=130,250$, (ii) Bathroom $=(325,624 /$ $40,000) \times 10,000=81,406$,

(iii) Dining Room $=(325,624 / 40,000) X 14,000=113,968$

b) ABC Overhead absorption rate of Sales Staff wages for

(i) Kitchen $=(64,800 / 4,400) \times 1,000=14,727$. (ii) Bathroom $=(64,800 / 4,400)$ $* 900=13,255$,

(iii) Dining Room $=(64,800 / 4,400) \mathrm{X} 2,500=36,818$

c) ABC Overhead absorption rate of Consultation Staff wages for

(i) Kitchen $=(24,960 / 1,248)$ X $798=15,960$, (ii) Bathroom $=(24,960 / 1,248) \mathrm{X}$ $200=4,000$,

(iii) Dining Room $=(24,960 / 1,248)$ X $250=5,000$

d) ABC Overhead absorption rate of Warehouse Staff wages for

(i) Kitchen $=(30,240 / 6,500) \times 1,000=4,652$, (ii) Bathroom $=(30,240 / 6,500) *$ $1,500=6,978$,

(iii) Dining Room $=(30,240 / 6,500) \times 4,000=18,609$

e) ABC Overhead absorption rate of Administration Staff wages for

(i) Kitchen $=(30,624 / 5,648) \times 1,798=9,749$, (ii) Bathroom $=(30,624 / 5,648) *$ $1,100=5,964$,

(iii) Dining Room $=(30,624 / 5,648) \times 2,750=14,911$

f) EBAC Overhead absorption rate of Sales staff wages for (i) Kitchen $=(1.00 / 2.225) \times 64,800=29,124$, (ii) Bathroom $=(0.6 / 2.225) \times 64,800$ $=17,474$,

(iii) Dining Room $=(0.625 / 2.225) \times 64,800)=18,202$

h) EBAC Overhead absorption rate of Consultation staff wages for

(i) Kitchen $=(0.8 / 0.994) \times 24,960=20,042$, (ii) Bathroom $=(0.133 / 0.994) X 24,960$ $=3,349$,

(iii) Dining Room $=(0.063 / 0.994) \times 24,960=1,570$

i) EBAC Overhead absorption rate of Warehouse staff wages for

(i) Kitchen $=(1.0 / 3.0) \times 30,240)=10,080, \quad$ (ii) Bathroom $=(1.0 / 3.0) \times 30,240$ $=10,080$,

(iii) Dining Room $=(1.0 / 3.0) \times 30,240=10,080$

j) EBAC Overhead absorption rate of Administration staff wages for

(i) Kitchen $=(1.8 / 3.219) \times 30,624=17,106$, (ii) Bathroom $=(0.733 / 3.219) \times$ $30,624=6,977$

(iii) Dining Room $=(0.688 / 3.219) \times 30,624=6.541$

k) EBAC Overhead absorption rate of General Overheads

(i) Kitchen $=(16.0 / 26.167) \mathrm{X} 175,000=107,006$, (ii) Bathroom $=(6.667 / 26.167) \mathrm{X}$ $175,000=44,586$

(iii) Dining Room $=(3.5 / 26.127) \times 175,000=23,408$ 
Table 9 Percentage of Change in Profit from TCS and ABC to EBAC - Home Style

\begin{tabular}{|c|c|c|c|c|c|}
\hline \multicolumn{6}{|c|}{ Percentage of change vs. EBAC } \\
\hline \multicolumn{2}{|c|}{ Kitchens } & \multicolumn{2}{|c|}{ Bathroom } & \multicolumn{2}{|c|}{ Dining Room } \\
\hline TCS & $\mathrm{ABC}$ & TCS & $\mathrm{ABC}$ & TCS & $\mathrm{ABC}$ \\
\hline$-317 \%$ & $-214 \%$ & $17 \%$ & -8 & $36 \%$ & $60 \%$ \\
\hline
\end{tabular}

The information given in Table 8 is the costing information calculated for total units of Kitchen, Bathroom and Dining Room. The results for Kitchen by using TCS show a profit of $\$ 16,750$. However by using ABC the profits go up to $\$ 31,911$. When compared to TCS, ABC is known to move cost from the high volume products to the low volume products. However moving overheads costs from high volume to low volume products without taking into account each product's level of efficiency in using or incurring those overheads is wrong. Kitchen has in fact been making losses when overheads are absorbed using EBAC. The results for Bathroom are even more contradicting under all three methods. The TCS reported Bathroom as making a loss of $\$ 6,406$ while ABC seems to suggest that it is actually making a profit of $\$ 1,053$.

However using EBAC actually makes a loss of $\$ 7,466$. Home style would have made a wrong decision on whether to continue or shutdown the Bathroom division based on $\mathrm{ABC}$ as compared to EBAC. Dining Room, which shows a reduced profit of $\$ 127,412$ based on $\mathrm{ABC}$ as compared to TCS, was actually performing well at a profit of $\$ 204,200$ based on EBAC. The more efficient Dining Room has been subsidizing the less efficient Kitchen and Bathroom. The percentage of change in profitability for Kitchen by adopting the EBAC as compared to TCS and $\mathrm{ABC}$ are $-317 \%$ and $-214 \%$ respectively while for Bathroom $17 \%$ and $-8 \%$ respectively and for Dining Room $36 \%$ and $60 \%$ respectively.

\section{Service Industry Scenario}

Pantai is a privately owned profit oriented hospital that specializes in operations Throat and Nose operations. Pantai traditionally determines its prices by adding a 10\% mark up to the budgeted full cost of an operation. The fixed overheads are absorbed on the basis of operating hours under the Traditional Costing System (TCS). The financial information of Pantai for the most recent year is as follow:

Department

Operating hours

Average duration of operation

Number of operations undertaken

Variable cost per operation

Fixed Overheads Total

$\begin{array}{cc}\text { Throat } & \text { Nose } \\ 2,988 & 4,572 \\ 3.0 \text { hours } & 3.6 \text { hours } \\ 996 & 1,270 \\ \$ 1,450 & \$ 1,254\end{array}$

Total

7,560

276,500

$\$ 12,000,000$

The breakdown of fixed overheads to be used for $\mathrm{ABC}$ and EBAC are as follow:
Activity
a) Consultations with potential patients
Cost driver
Throat Nose
Fixed Overheads
Number of consultations $\quad 3,000 \quad 2,000$
$\$ 8,980,000$
b) X-rays
Number of X-rays $\quad 6,200 \quad 6,200$
$\$ 1,800,000$
c) Post-operative care
Days of care
$7,860 \quad 23,580$
$\$ 1,220,000$

The calculation of the overhead absorption rate using the TCS, ABC and EBAC is given below:

Table 10 Calculation of TCS overhead absorption rate - Pantai

\begin{tabular}{|l|c|c|c|}
\hline Cost Pool & $\$$ & Driver & AR \\
\hline Total overhead costs & $12,000,000$ & Operating hours & $12,000,000 / 8,000=1,500$ \\
\hline
\end{tabular}

Note: a) $\mathrm{AR}=$ Absorption rate 
Table 11 Calculation of ABC overhead absorption rate- Pantai

\begin{tabular}{|l|c|c|c|c|}
\hline Cost Pool & $\$$ & Driver & & AR/Driver \\
\hline Consulting & $8,980,000$ & No of consultations & 5,000 & 1796 \\
\hline X-ray & $1,800,000$ & Number of X-rays & 12,400 & 145.2 \\
\hline Post operative care & $1,220,000$ & Days of care & 31440 & 38.8 \\
\hline
\end{tabular}

Table 12 Calculation of EBAC overhead absorption rate- Pantai

\begin{tabular}{|c|c|c|c|c|c|c|c|c|c|c|}
\hline \multirow[t]{2}{*}{ Cost Pool } & \multirow[t]{2}{*}{$\$$} & \multirow[t]{2}{*}{ Driver } & \multicolumn{3}{|c|}{ Throat } & \multicolumn{3}{|c|}{ Nose } & \multirow{2}{*}{$\begin{array}{l}\text { Total no } \\
\text { of drivers }\end{array}$} & \multirow{2}{*}{$\begin{array}{c}\text { Total } \\
\text { ER }\end{array}$} \\
\hline & & & $\begin{array}{c}\text { No of } \\
\text { drivers }\end{array}$ & $\begin{array}{l}\text { No of } \\
\text { units }\end{array}$ & ER & $\begin{array}{l}\text { No of } \\
\text { drivers }\end{array}$ & $\begin{array}{l}\text { No of } \\
\text { units }\end{array}$ & ER & & \\
\hline Consulting & $8,980,000$ & $\begin{array}{c}\text { No of } \\
\text { consultations }\end{array}$ & 3,000 & 996 & 3.01 & 2,000 & 1,270 & 1.57 & 5,000 & 4.59 \\
\hline X-ray & $1,800,000$ & Number of X-rays & 6,200 & 996 & 6.22 & 6,200 & 1,270 & 4.88 & 12,400 & 11.11 \\
\hline $\begin{array}{l}\text { Post } \\
\text { operative } \\
\text { care }\end{array}$ & $1,220,000$ & Days of care & 7,860 & 996 & 7.89 & 23,580 & 1,270 & 18.57 & 31,440 & 26.46 \\
\hline
\end{tabular}

Note: a) ER = Efficiency rate
b) Consulting cost ER for
(i) Throat $=3,000 / 996=3.01$,
c) X-Ray cost ER for
(i) Throat $=6,200 / 996=6.22$,
d) Post operative care cost ER for (i) Throat $=7,860 / 996=7.89$,
(ii) Nose $=2,000 / 1,270=1.57$
(ii) Nose $=6,200 / 1,270=4.88$
(ii) $23,580 / 1,270=18.57$

Table 13 Cost and Profitability of Products under different costing methods- Pantai

\begin{tabular}{|c|c|c|c|c|c|c|c|c|c|c|}
\hline & \multicolumn{3}{|c|}{ Throat } & \multicolumn{3}{|c|}{ Nose } & \multicolumn{4}{|c|}{ Percentage of Change vs. EBAC } \\
\hline & $\$$ & $\$$ & $\$$ & $\$$ & $\$$ & $\$$ & \multicolumn{2}{|c|}{ Throat } & \multicolumn{2}{|c|}{ Nose } \\
\hline & TCS & $\mathrm{ABC}$ & EBAC & TCS & $\mathrm{ABC}$ & EBAC & TCS & $\mathrm{ABC}$ & TCS & $\mathrm{ABC}$ \\
\hline Variable costs & 1450 & 1450 & 1450 & 1254 & 1254 & 1254 & & & & \\
\hline Fixed Costs & 4500 & & & 5400 & & & & & & \\
\hline Consulting & & $5,409.6$ & 5920.6 & & $2,828.3$ & 2427.6 & & & & \\
\hline X-ray & & 903.6 & 1012.9 & & 708.7 & 623.0 & & & & \\
\hline Post operative care & & 306.2 & 365.3 & & 720.5 & 674.1 & & & & \\
\hline Total costs & 5950 & 8069.5 & 8748.8 & 6654 & 5511.5 & 4978.7 & & & & \\
\hline $10 \%$ Mark Up & 595 & 807 & 874.9 & 665.4 & 551.1 & 497.9 & & & & \\
\hline Price & 6545 & 8876.4 & 9623.7 & 7319.4 & 6062.6 & 5476.6 & $47 \%$ & $8 \%$ & $-25 \%$ & $-10 \%$ \\
\hline
\end{tabular}

Note: a) TCS Overheads absorption rate for

(i) Throat $=(12,000,000 / 8,000) \times 3=4,500$, (ii) Nose $=((12,000,000 / 8,000) \times 3.6=5,400$

b) ABC Overhead absorption rate of Consulting cost for

(i) Throat $=[(8,980,000 / 5,000) \times 3,000] / 996=5,409.6$,

(ii) Nose $=[(8,980,000 / 5,000) X 2,000] / 1,270=2,828.3$

c) $\mathrm{ABC}$ Overhead absorption rate of $\mathrm{X}$-ray cost for

(i) Throat $=[(1,800,000 / 12,400) \times 6,200] / 996=903.6$,

(ii) Nose $==[(1,800,000 / 12,400) \times 6,200] / 1,270=708.7$

d) ABC Overhead absorption rate of Post operative care for

(i) Throat $=[(1,220,000 / 31,440)] \times 7,860] / 996=306.2$,

(ii) Nose $=[(1,220,000 / 31,440) X 23,580] / 1,270=720.5$

e) EBAC Overhead absorption rate of Consulting cost

(i) Throat $=[(3.01 / 4.59) \times 8,980,000] / 996=5,920.6$,

(ii) Nose $=[(1.57 / 4.59) \times 8,980,000] / 1,270=2,427.6$,

f) EBAC Overhead absorption rate of $X$-ray cost

(i) Throat $=[(6.22 / 11.1) \times 1,800,000] / 996=1,012.9$,

(ii) Nose $=[(4.88 / 11.1) \times 1,800,000] / 1,270=623.0$

g) EBAC Overhead absorption rate of Post operative care cost

(i) Throat $=[(17.89 / 26.46) \times 1,220,000] / 996=365.3$,

(ii) Nose $=[(18.57 / 26.46) \times 1,220,000] / 1,276=674.1$

The information given in Table 13 is costing information calculated for each unit of Throat and Nose operation. The cost information for X-ray cost is a good example of the different absorption characteristics of ABC 
versus EBAC. The number of X-rays, which is the cost driver for X-ray cost, is the same for both Throat and Nose i.e. 6,200. The $X$-rays cost allocated by using $A B C$ in total to Throat operations would be $\$ 900,000$, i.e. ( $\$ 145.2 X$ 6,200 ) and to Nose would be also $\$ 900,000$. The same amount of allocation of cost happens because ABC allocates the X-rays cost using a standard absorption rate of \$ 145.2 and since both Throat and Nose utilized the same number $\mathrm{X}$-rays, they are both given an equal share of the total $\mathrm{X}$-rays cost. $\mathrm{ABC}$ however does not take into account the different number of operations carried for Throat and Nose as an important criteria for cost absorption. EBAC on the other hand, recognizes the different level of efficiency of both operations in using or utilizing X-rays cost although the number of cost drivers utilized is the same. Therefore EBAC allocates X-rays cost in total to all Throat operations to $\$ 1,008,826$, i.e. [(6.22/11.1) X 1,800,000)] and Nose to $\$ 791,174$, i.e. [(4.88/11.1) X 1,800,000]. EBAC did not allocate the same proportion of total X-rays cost to both operations because although the numbers of cost drivers incurred by both operations are the same, the number of operations for Throat is 996 while for Nose is 1,270. In this regard, Nose has been more efficient than Throat in utilizing the X-rays cost and therefore allocated lesser total cost compared to Throat.

The price charged for Throat operation under TCS is $\$ 6,545$ and under ABC is $\$ 8,876.4$ while under EBAC is $\$ 9,623.7$. The price charged for Nose operation under TCS is $\$ 7,319.4$ and ABC is $\$ 6,062.6$ while under EBAC is $\$ 5,476.6$. $\mathrm{ABC}$ has no doubt moved the fixed cost from the high volume Nose operation to the low volume Throat operation. However it is clear by using EBAC, that Nose has been more efficient in incurring overheads and therefore subsidizing the less efficient Throat. Pantai has been over charging its customers for the Nose operation while under charging for the Throat operation. Throat has therefore been making a loss under the price charged by the TCS and ABC. The percentages of change in profitability by adopting the EBAC as compared to TCS and ABC for Throat are $47 \%$ and $8 \%$ respectively. The percentages of change in profitability by adopting the EBAC as compared to TCS and $\mathrm{ABC}$ for Nose are $-25 \%$ and $-10 \%$ respectively.

\section{DISCUSSION}

In the past researchers have learnt and highlighted some of the weakness of traditional costing system (TCS) and activity based costing. As a result the search for a more accurate methodology for absorbing cost has ensued ever since. However the domain of absorption costing has not evolved much since ABC and only two methodologies have been put forward thus far. The first methodology has been termed 'transaction costing' (TC) (Cooper and Kaplan, 1988). ${ }^{1}$ Transaction costing proponents saw the weakness of the traditional costing system that assigns costs to products using a single volume-related base in distorting costs. TC reasoned that a different type of allocation base should be used for overhead costs that vary with the number of transactions performed, as opposed to volume of product produced. In the traditional costing system, the costing element is the product or service or it is the product or service that gets costed while in TC the costing element is any element that affects transaction. One the other hand the weakness of $\mathrm{ABC}$ is using a single blanket standard absorption rate for each cost pool was not highlighted by TC. However TC never gained the momentum ABC enjoyed both in practice (and teaching). In TC system, costs are assigned to the units that caused the transaction to be originated. An example of a transaction is set up and its costing element will be production lot because each production lot requires a single set up. In a TC system, the unit cost of a product is determined by dividing the cost of transaction (production lot cost) by the units in the production lot. However TC has a number of weaknesses. For example any firms' set up cost would be made up of staff costs, maintenance costs, lubricants costs and etc. Difficulty lies in deciding, for example how to split the set up unit or department staff costs to the various production lots carried out in a period. Although it is possible to track the hours spend by the set up staff for each production lot, such measures would not be feasible in practice due to the high level of resources required to gather, store and make available staff hour data for calculation of costs. As a result some sort of arbitrary allocation technique is still needed to determine each production lots' cost. In this regard, the better way to arbitrarily allocate overhead costs is to allocate it to it final destination i.e. its product or service as directing overhead to other destinations like transactions could only further distort costs. The next weakness of TC lies in its inability to cope with the cost data generating demands of businesses with highly heterogeneous products, services or customers, (Barret 2008). Certain type of business like retail banking, parcel delivery and custom-made-manufacturing produce or offer highly heterogeneous product and service that needs cost

\footnotetext{
${ }^{1}$ The concept of Transaction Costing and its methodology is explained in detail by Cooper and Kaplan (1988) in their article titled "How cost accounting distorts product costs".
} 
data to be generated at granular level of detail in order to use the TC. However the ability, resource and time needed to produce thousands of individual cost data for each parcel delivery or each customer order is so laborious in that many organizations shy away from adopting TC.

The second methodology for absorption costing comes from Kaplan and Anderson (2005). ${ }^{2}$ The traditional $\mathrm{ABC}$ seemed to have come under fire from its earliest and most active proponents (Tony 2008). The traditional ABC will hereafter be referred to as simply $\mathrm{ABC}$ for clarity purposes. The new or modified methodology was termed the Time-Driven Activity Base Costing (TDABC). However seasoned practitioners in the cost management field recognized that this "new" methodology was anything but new. The application of TDABC is said to require only two parameters, which is the unit cost of supplying capacity and the time required to perform a transaction or an activity. TDABC is also said to be a pull-based system, simpler, less costly and faster to implement. The literature on absorption costing post- $\mathrm{ABC}$ identifies two types of cost drivers, which are the transactional cost drivers and duration cost drivers (Cooper 1988). The transactional cost drivers count the number of times an activity is performed and examples include number of set ups, number of production runs, number of shipments, number of purchase orders and number of customer orders. The duration cost drivers estimate the time required in performing each activity and examples include set up hours, material handling time, direct labor hours and machine hours. The duration cost drivers are generally more accurate but also more expensive to measure (Kaplan and Anderson 2005). Most $\mathrm{ABC}$ systems have been found to use a large number of transactional cost drivers although some have incorporated the use of duration cost drivers. Both types of drivers could be easily used for ABC and EBAC cost calculations without any additional arithmetic techniques done as shown by the analysis of the three scenarios earlier in this paper. TDABC uses the practical capacity of the resources supplied to calculate its absorption rate and primarily uses the duration cost drivers for its analysis. The absorption rate in TDABC is obtained first by dividing the cost of capacity supplied with the practical capacity of resources supplied to obtain the cost per minute and next multiplying the cost per minute with the number of activity. For example a customer service department which is a supplying capacity incurs $\$ 630,000$ and requires 30 customer services employees with each employee supplying 30,000 minutes per quarter. The practical capacity is assumed to be at $80 \%$ or 24,000 minutes per employee and in total 720,000 minutes per quarter. Using TDABC, the cost per minute would therefore be $\$ 0.875$ $(\$ 630,000 / \$ 720,000)$. Assuming the customer service department services are divided into three customer-related activities i.e. handling customer orders, process customer complaints and perform credit checks. The "handling customer orders' estimated capacity is 40 minutes and therefore the cost absorbed would be $\$ 35-(\$ 0.875 \mathrm{X} 40)$. TDABC uses the estimated capacity to absorb costs (e.g. 40 minutes for handling customer orders) and not the practical capacity unlike $\mathrm{ABC}$ and $\mathrm{EBAC}$ and would therefore reveal the portion of unused capacity of the practical capacity. The unused capacity information is said to be used in TDABC to obtain information about the cost and the underlying 'efficiency' of each activity as well as the quantity or hours and cost of the unused capacity in the resources supplied to perform the activity. However TDABC would still need to carry out a second round allocation of the total cost assigned to each activity to individual product for certain decision making situation like pricing. In this regard, TDABC has the same weakness of Transaction Costing (TC) where overhead cost is not initially directed straight towards products or services but to transactions and activities before being redirected to products and services. EBAC eliminates this phenomenon by straight away directing overhead costs to products and services. Additinaly TDABC does not link to the cost of unused capacity to the ultimate output of firms i.e. product and services. It would not also be clear as to which product or service should benefit when an improvement in unused capacity is achieved because different product and services have different efficiency level in utilizing or using the overheads as pointed out by EBAC. In EBAC the responsibility of the overhead utilization efficiency partly lies with the managers of each product or division. It is recognized that the efficiency of product or services in utilizing overheads is in part also contributed by the overhead department or units' productivity. TDABC tries to unearth the productivity or 'efficiency' level of the overhead departments by highlighting the unused capacity. However TDABC does not clearly link unused capacity to products and services but reveals it in total for the firm. The TDABC information on unused capacity would therefore be unable to assist management in crucial decisions scenarios like make or buy, to accept or reject a special order, to continue or shut down a cost/revenue centre, how much to price products and services. EBAC on the other hand which is more similar in methodology to ABC as

\footnotetext{
${ }^{2}$ The concept of Time Driven ABC (TDABC) by Kaplan and Anderson (2005) in their article titled "Rethinking Activity Based Costing" gives an overview of TDABC and provides few scenarios with numerical illustration. Readers could refer this article to obtain a full picture on TDABC's methodologies and to better apprehend the example discussed above in this paper above.
} 
compared to TDABC provides the information needed for the decision making scenarios highlighted above. Next the proponents of TDABC claim that it is easier and faster to estimate than $\mathrm{ABC}$. TDABC is said to eliminate the need to interview, observe and record estimate the amount of time spent on each activities because in TDABC managers will estimate the units of time required to perform an activity. This change of method to obtain information on the time spend on each activity is not necessarily better. This is because the estimate given by the managers might not be accurate and allow them to introduce budget slack in the estimation process. In contrast, the collection of activity information in $\mathrm{EBAC}$ and $\mathrm{ABC}$ is a more wide-ranging technique and could prevent bias and error in information collected. Furthermore TDABC is found to only suit certain firms and is not a one-size-fits-all methodology unlike EBAC or $\mathrm{ABC}$. $\mathrm{ABC}$ is proven to be successfully implemented in a variety of industries. $\mathrm{EBAC}$ is envisaged to applicable to all industries as it is modeled more closely with $\mathrm{ABC}$ and as shown by the analysis of the three scenarios above. In practice, like TC, TDABC also never gained the momentum and popularity ABC enjoyed.

The positive side of TDABC is it could be useful for budget-variance analysis as managers can compare the planned capacity versus the estimated capacity and thereby take corrective actions. Both TDABC and EBAC have different methodologies to arrive at their calculation from different directions to account for the same overheads. TDABC could therefore be applied alongside EBAC for firms who could afford having two systems as the unused capacity information could be useful in assessing the performance of each overhead department in totality.

EBAC is a methodology that is both easy and convenient to apply. Firms currently using ABC could instantly explore the more accurate EBAC as no new data collection effort is required. EBAC utilizes all the existing information like cost drivers and cost pools that $\mathrm{ABC}$ system provides without the need for any extra information. More firms currently using TCS is anticipated to adopt the more accurate and efficient based EBAC as results of empirical studies reveal an increasing trend among firms adopting better and accurate costing methodologies.

\section{CONCLUSION}

An attempt has been made in this paper to present an improved, efficiency based absorption costing methodology coined the efficiency based absorption costing (EBAC). EBAC represent an algorithm that absorbs costs based on efficiency as the main driver and we compare its results with other methods such as ABC as proof-ofconcept. This research is timely due to the current global financial crisis which exerts heightened demands on firms to ensure survival. Possession of accurate and efficient information is vital for firms to make the best business decisions. A shift in mindset and methodology is therefore crucial because we really have to rethink as to how costs are inefficiently absorbed leading to inaccurate cost planning and decision making. The potential benefits that EBAC offers management accounting practices and businesses in general are really enormous. As indicated by the analysis given above, using the more accurate and efficient EBAC results in significant cost changes as compared to $\mathrm{ABC}$ or TCS. Businesses could embrace the more efficient EBAC for a host of their pertinent cost control and decision making needs like to make or buy, to accept or reject a special order, to continue or shut down a cost/revenue centre, how much to price products and services and how much resources to allocate to different products and establish output volume levels. The full products costing approach like EBAC are the main determinant of product prices (Drury et al. 1993; Friedman and Lyne 1995). The process of performance measurement and appraisals of managers of cost/profit/investment centers and business units will also result in improved accuracy and fairness under EBAC. Our approach in introducing improved methodologies to enhance results would be greatly appealing to management accountants, project management executives, cost planners, manufacturers and etc. as they become more competent in cost analysis and make better and more accurate decisions.

While previous studies have found $\mathrm{ABC}$ appear to a have a great deal to offer to TQM organizations (Steve and Ken 1994), the potential benefits of EBAC to these organizations should be even greater. The advent of the modern business environment has seen the emergence and adoption of contemporary management philosophies by businesses. These larger- than-life philosophies include Total Quality Management (TQM), Just-in-Time (JIT) and Lean manufacturing. In Lean manufacturing for example, the second out of its five fundamental principles outlines the need to 'identify the value stream for products and services' (Womack and Jones 1996). The EBAC methodology proposed above have been more accurate in calculating the value stream of products and services. 
Hence the applications of the more efficient based EBAC on modern business environments is potentially enormous and in need to be empirically tested. The proposed EBAC model is currently being tested empirically in business environments covering TQM, JIT and Lean based and traditional ones. Participating businesses comprise a good mix of different industry sectors and are made up of international and local businesses. The results of the empirical study currently on-going will be reported in the near future. It is also hoped that more research initiatives on EBAC would be carried out by future researchers.

\section{AUTHOR INFORMATION}

Samuel Jebaraj Benjamin is an accounting lecturer at the Faculty of Management, Multimedia University, Cyberjaya Campus, Cyberjaya, Selangor, Malaysia. He is currently pursuing his PhD in Multimedia University. His areas of interest in research are management accounting, and financial reporting.

Saravanan Muthaiyah received his Ph.D. in Information Technology from the Volgenau School of Information Technology and Engineering, Department of Computer Science, George Mason University, USA. He is a researcher at the Faculty of Management, Multimedia University, Cyberjaya, Malaysia. He is also a Fulbright Scholar and Fellow. Dr. Muthaiyah's research in the area of Accounting Information Systems, Systems Engineering, Semantic Web, Programming, Costing Methodologies and Knowledge Management. He has published more than thirty papers in international journals, books, workshops and conference proceedings. His corporate experience includes working with IBM World Trade Corporation, Intel and Arthur Anderson. He is currently the Deputy Dean of Postgraduate matters at the Faculty of Management, Multimedia University, Cyberjaya, Malaysia.

M. Srikamaladevi Marathamuthu is an accounting information systems and management lecturer at the Faculty of Management, Multimedia University, Cyberjaya Campus, Cyberjaya, Selangor, Malaysia. She is and currently pursuing her $\mathrm{PhD}$ in Multimedia University. Her areas of interest in research are information system, information security and management accounting.

\section{REFERENCES}

1. Acton, D., \& Cotton, W. (1997). Activity-based costing in a university setting. Journal of Cost Management (USA), 11(2), pp. 32-8.

2. Adams, M. (1996). Activity-based costing (ABC) and the life-insurance industry. Service Industries Journal , 16( 2), pp. 511-26.

3. Agrawal, S., \& Mehra, S. (1998). Cost Management system: an operational overview. Managerial Finance , 24(1), pp. 60-78.

4. Aird, B. (1996). Activity-based cost management in health care - another fad? International Journal of Health Care Quality Assurance, 9(4), pp. 16-19.

5. Anderson, S., \& Young, S. (1999). The impact of contextual and process factors on the evaluation of activity-based costing systems. Accounting, Organizations and Society ,24, pp. 525-559.

6. Bailey, J. (1991). Implementation of ABC systems by UK companies. Management Accounting (UK), pp.30-31.

7. Barnes, P., \& Webb, J. (1986). Management Information Changes and Functional Fixation: Some Experimental Evidence from the Public Sector. Accounting, Organizations and Society, 11(1), pp. 1-18.

8. Barrett, R. (2008). The Challenges of Transactional Costing. Journal of Performance Management, 21(1), pp. 3-9.

9. Baykasoglu, A. (2001). Process modelling for manufacturing process selection. Teknoloji, 24(1), pp. 8394.

10. Baykasoglu, A., \& Kaplanoglu, V. (2007). A service-costing framework for logistics companies and a case study. Management Research News, 30(9), pp. 621-633.

11. Baykasoglu, A., Dereli, T., Yilankirkan, A., \& Yilankirkan, N. (2003, April 19-20). Application of activity based costing to a SME in Gaziantep. Ulusal Uretim Arastirmalari Sempozyumu Bildiriler Kitabi, Kultur Universitesi, Istanbul, pp. 235-42. 
12. Baykasoglu, A., Yurdakul, M., \& Baykasoglu, C. (2006, 22-23 September). Benzetim temelli faaliyet tabanli maliyetlendirme ve bir KOB'ye uygulanmasi (in Turkish), UAS' 06: VI. Ulusal Uretim Arastirmalari Sempozyumu, Istanbul, pp. 3-11.

13. Bloom, R., Pieter T., E., \& Dennis, M. (1984). Functional Fixation in Product Pricing: A Comparison of Individuals and Groups. Accounting, Organizations and Society , 9(1), pp.1-11.

14. Caplan, D., Melumad, N. D., \& Ziv, A. (2005). Activity-Based Costing and Cost Interdepencies among Products: The Denim Finishing Company. Issues in Accounting Education, 20(1), pp. 51-62.

15. Chenhall, R. (2003). Management control systems design within its organizational context: findings from contingency-based research and direction for the future. Accounting, Organizations and Society, 28, pp. 127-168.

16. Chenhall, R., \& K., L.-S. (1998). Adoption and benefits of management accounting practices: an Australian study. Management Accounting Research, 9, pp. 1-19.

17. Cooper, R. (1990). Cost classification in unit-based and activity-based manufacturing cost systems. Journal of Cost Management , 4(3), pp. 2-14.

18. Cooper, R., \& Kaplan, R. (1992). Activity-based systems: measuring the costs of resource usage. Accounting Horizons , 6(3), pp. 1-13.

19. Cooper, R., \& Kaplan, R. (1991). Profit priorities from activity based costing. Havard Business Review , 69(3), pp. 130-135.

20. Cooper, R., \& Kaplan, R. S. (1988). How Cost Accounting Distorts Product Costs. Management Accounting , 69(10), pp. 20-27.

21. Cooper, R. (1988). The Rise of Activity-Based Costing-Part One: What is an Activity-Based Cost System?. Journal of Cost Management, pp. 45-58.

22. Coskins, G. (1997). If activity based costing is the answer, what is the question? IIE Solutions, 29(8), pp. 38-42.

23. Dennis P, T., \& Peter, C. (1988). Product Pricing Behaviour Under Different Costing Systems. Accounting and Business Research, 18(71), pp. 257-265.

24. Dhavale, D. (1993). Activity-based costing in cellular manufacturing. Journal of Cost Management , 7(1), pp. 13-27.

25. Dickhaut, J. W., \& John C., L. (Autumn 1983). Comparison of Accounting Systems and Heuristics in Selecting Economic Optima. Journal of Accounting Research , 21(2), pp. 495-513.

26. Drake, A. R., \& Haka, S. F. (2008). Does ABC Information Exacerbate Hold-Up Problems in BuyerSupplier Negotiations? The Accounting Review , 83(1), pp. 29-60.

27. Drury, C., \& Tayles, M. (2000). Cost System Design and Profitability Analysis in UK Companies. London: The Chartered Institute of Management Accountants.

28. Drury, C., \& Tayles, M. (1994). Product costing in UK management organisations. European Accounting Review, 3(3), pp. 443-69.

29. Drury, C., Braund, S., Osborne, P., \& Tayles, M. (1993). A Survey of Management Accounting. London: The Chartered Association of Certified Accountants.

30. Emblemsvag, J. (2007). Using activity-based costing and economic profit to grow the bottom-line. Business Strategy Series , 8(6), pp. 41-425.

31. Friedman, A., \& Lyne, S. (1995). Activity-based Techniques: The Real Life Consequences. London: The Chartered Institute of Management Accountants.

32. Gietzmann, M. (1991). Implementing issues associated with the construction of an activity-based costing system in an engineering manufacturer. Management Accounting Research , 2(2), pp. 189-99.

33. Gordon, L. A., Robert, C., Falk, H., \& Miller, D. (1981). The Pricing Decision. National Association of Accountants and The Society of Management Accountants of Canada .

34. Govindarijian, V., \& Anthony, R. N. (1983). How Firms Use Cost Data in Pricing Decisions. Management Accounting , pp. 30-31, 34-36.

35. Greeson, C., \& Kocakulah, M. (1997). Implementing an ABC pilot at whirlpool. Journal of Cost Management, 11(2), pp. 16-21.

36. Gunasekaran, A., Marri, H., \& Yusuf, Y. (1999). Application of activity-based costing: some case experiences. Managerial Auditing Journal , 14(6), pp. 286-293.

37. Gupta, M., \& Galloway, K. (2003). Activity-based costing/management and its implications for operations management. Technovation, 23, pp. 131-8. 
38. Gurd, B., Smith, M., \& Swaffer, A. (2002). Factors impacting on accounting lag: an exploratory study of responding to TQM. British Accounting Review, 34, p. 205-221.

39. Hopper, T., Kirkham, L., Scapens, R., \& Turley, S. (1992). Does financial accounting dominate managment accounting A research note. Management Accounting Research, 3(3), pp. 307-11.

40. John A., B., Christopher J., C., \& Drury, C. (2001). How product costs are calculated and used in decision making: a pilot study. Managerial Auditing Journal , pp. 202-206.

41. John Innes, Mitchell, F. (1995). A survey of activity-based costing in the U.K.'s largest companies. Management Accounting Research , 6, pp. 137-153.

42. John Innes, M. F., \& Sinclair, D. (2000). Activity-based costing in the U.K.'s largest companies: a comparison of 1994 and 1999 survey results. Management Accounting Research , 11, pp. 349-362.

43. Johnson, H., \& Kaplan, R. (1987). Relevance lost: the Rise and Fall of Management Accounting. Boston, MA: Havard Business School Press.

44. Kaplan, R. (1998). Advanced Management Accounting. Upper Saddle River, NJ: Prentice-Hall.

45. Kaplan, R. (1984). The Evolution of Management Accounting. The Accounting Review , pp. $390-396$.

46. Kellett, B., \& Sweeting, R. (1991). Accounting innovations and adaptions: a UK case. Management Accounting Research, 2(1), pp. 15-26.

47. Landry, S., Wood, L., \& Lindquis, T. (1997). Can ABC bring mixed results? Management Accounting , 78(9), pp. 28-33.

48. Lere, J. C. (1982). Output Quantity and Price Decisions Based on Accounting Costs: The Downward Sloping Demand Case. unpublished working paper .

49. Lere, J. C. (1986a). Product Pricing Based on Accounting Costs. Accounting Review , LXI (2), pp. $318-324$.

50. Lukka, K., \& shields, M. (1999). Innovations in management accounting focus. Management Accounting , 77(3), pp. 33-38.

51. Lyne, S., \& Friedman, A. (1996). Activity-based techniques and the new mangement accountant. Management Accounting, July/August, pp. 34-8.

52. Magdy, A.-K., \& Luther, R. (2006). Management Accounting Practices in the British Food and Drinks Industry. British Food Journal , 108(5), pp. 336-357.

53. Marquis, L. M., \& Ruh, L. (2008). Cost Allocations For Hospital Management. Journal of the International Academy for Case Studies, 14(8), pp. 93-97.

54. Matz, A. (1950). Marginal Cost. New York Certified Public Accountant (pre-1986) , 20(000006), pg. 355359.

55. Michael, C., D., W., \& Susan B., W. (1988). How Do Companies Analyze Overhead? Management Accounting , 69(12), pp. 41.

56. Michela, A., \& Irvine, L. (2005). Activity Based Costing in Healthcare: A UK Case Study. Research in Healthcare Financial Management, 10(1), pp. 61-75.

57. Miller, A. (1996). Activity Based Management in Daily Operation. Chichester, UK: John Wiley \& Sons.

58. Nazmi, S. J., Malcolm, S., \& Colin, D. (2007). Perceptions of preparers and users to accounting change: a case study in an Australian university. Managerial Auditing Journal , 22(1), pp. 80-94.

59. Robert, S. Kaplan \& Steven R., A. (2005. Rethinking Activity-Based Costing. Havard Business Review.

60. Ruhanita, M., \& Daing, N. I. (2007). Factors Influencing Activity Based Costing (ABC) Adoption in Manufacturing Industry. Investment Management \& Financial Innovations , 4(2), pp. 113-124.

61. Ruhl, J., \& Hartman, B. (1998). Activity-based costing in the services sector. Advances in Management Accounting , 6, pp. 147-61.

62. Scapens, R., Turley, S., Burns, J., Lewis, L., Joseph, N., \& Southworth, A. (1996). External Reporting and Management Decisions: A Study of their Interrelationship in UK Companies. London: The Chartered Institute of Management Accountants.

63. Scheeweiss, C. (1998). On the applicability of activity-based costing as a planning instrument. International Journal of Production Economics , 54(3), pp. 277-84.

64. Sharman, P. A., \& Vikas, K. (2004). Lessons from German. Strategic Finance, 86(6), pp. 28-35.

65. Shields, M. (1995). An empirical analysis of firms' implementation experiences with activity-based costing. Journal of Management Accounting Research , 7, pp. 148-61.

66. Smith, M. (2000). Innovation diffusion. Financial Management, pp. 40-1.

67. Snyder, H., \& Davenport, E. (1997). What does it really cost? Allocating indirect costs. Asian Libraries , 6(3/4), pp. 205-214. 
68. Sohal, A., \& Chung, W. (1998). Activity based costing in manufacturing: two case studies on implementation. Integrated Manufacturing Systems, Vol. 9 (No. 3), pp. 137-47.

69. Steve R., L., \& Ken, G. (1994). Should Activity-based Costing Be Considered as the Costing Method of Choice for Total Quality Organizations? The TQM Magazine , 6(5), pp.1-7.

70. Thomas, A. L. (1969). The Allocation Problem in Financial Accounting Theory. American Accounting Association Studies in Accounting Research, pp. 3.

71. Tony, A. (2008). Five myths about time-driven activity-based costing: The straight facts about traditional and time-driven costing methodologies. Available via SAS.

http://www.sas.com/news/sascom/2008q2/feature_abc.html. Cited 29 April 2009

72. Tony, T., \& Philip, W. (2001). ABC/TA for Internet Retail Shopping. International Journal of Retail \& Distribution Management, 29(4), pp. 149-155.

73. Tsai, W., \& Kuo, L. (2004). Operating costs and capacity in the airline industry. Journal of Airport Transport Management, 10, pp. 271-7.

74. Womack, J., \& Jones, D. (1996). Lean thinking: Banish waste and create wealth in your cooperation. New York: Simon and Schuster.

75. Yoshikawa, T., Innes, J., \& Mitchell, F. (1989, November). 1989. Japanese management accounting: A comparative survey, pp. 20-3.

76. Zhuang, L., \& Burns, G. (1992). Activity-based costing in non-standard route manufacturing. International Journal of Operations \& Production Management, 12(3), pp. 38-60.

77. Zimmerman, J. L. (1979). The Cost and Benefits of Cost Allocations. Accounting Review , LIV(3), pp. 504521. 